Informatika i sistemy upravleniya. - 2016. - No. 4(50). - P. 23-32.

Mikhailov M.M., Scherban D.S. (dmitriy1987@bk.ru)

Amur State University

\title{
MODELING OF INFRA-RED SPECTRUMS OF ALKALINE-HALOID CRYSTALS
}

Is a mathematical description of elastic ionic polarization of the two-component dielectric crystal caused by action of weak electric field is considered. Analysis of existing models, as well as the proposed parametric synthesis of the best of them.

Keywords: complex dielectric permeability, cybernetic model, parametrical synthesis, computing experiment.

DOI: 10.22250/isu.2016.50.23-32

For citation:

Mikhailov M.M., Scherban D.S. MODELING OF INFRA-RED SPECTRUMS OF ALKALINEHALOID CRYSTALS // Informatika i sistemy upravleniya. - 2016. - No. 4(50). - P. 23-32. 